\title{
Modeling and Simulation of the Photovoltaic Cells for Different Values of Physical and Environmental Parameters
}

\author{
Azem Hysa ${ }^{a^{*}}$ \\ "Applied and Natural Sciences Department, “Aleksander Moisiu” University, Durres, Albania
}

\begin{abstract}
Both research and technological development in the area of renewable energy sources are necessary to account for the increase in energy demand and environment problems in the world. The photovoltaic $(\mathrm{PV})$ cell has been described by non-linear outputs characteristics in current-voltage and power-voltage. This outputs is affected by various effects such as; series resistance $\left(R_{S}\right)$, shunt resistance $\left(R_{s h}\right)$, solar irradiance and temperature. In this paper the effect of variation of parameters has been studied such as series resistance $\left(R_{S}\right)$ and shunt resistance $\left(R_{s h}\right)$ of the diode in the photovoltaic cell and these effects could be seen in the Current-Voltage (I-V) and Power-Voltage (PV) characteristic curves. In this paper also has been studied the effect of variation of the environmental parameters such as solar irradiance and temperature. Results show that a higher temperature at constant solar irradiance produces a decrease power. So the voltage and the photovoltaic cell output power tend to decrease at higher temperatures, but there is no noticeable effect on the photovoltaic cell current. Thus, it is important to keep the cell temperature as low as possible, because higher temperatures have negative effect on output power of photovoltaic cell. On the other hand, the effect of solar irradiance on photovoltaic cell, it reveals that higher solar irradiance gives higher current and higher power. Shunt resistance has significant effect on the operating characteristic curves of PV cells as low power output is recorded if the value of shunt resistance varies from $0.07 \mathrm{ohms}$ to $1700 \mathrm{ohms}$. Finally, I have presented power-voltage characteristic curves and current voltage characteristic curves of photovoltaic cell for different solar irradiance in Shkoder, Tirana and Vlore.
\end{abstract}

Keywords:

Photovoltaic Cell;

Current-voltage Characteristic Curves;

Power-voltage Characteristic Curves;

Simulation;

MATLAB®.
Article History:

$\begin{array}{llll}\text { Received: } & 29 & \text { September } & 2019 \\ \text { Accepted: } & 24 & \text { November } & 2019 \\ \text { Published: } & 01 & \text { December } & 2019\end{array}$

\section{1- Introduction}

The photovoltaic cell is the basic unit of any photovoltaic system. The photovoltaic cells are in fact large area semiconductor. A photovoltaic cell can convert photon energy in to the form of electrical signals, this method of power generation do not harm to ecosystem hence PV power generation systems are becoming popular for generation in small scale as well as in large scale production [1]. In this context, several papers have been proposed different models, the most used is; single and double diode models. The single diode model is widely used for its simplicity and easy to implement in various software. It is called model with five parameters and characterized by photocurrent source parallel with diode and shunt resistance. The detailed single diode models has been proposed to determine the behavior of photovoltaic cell under different solar levels and temperatures [2]. The current-voltage and power-voltage are used to describe the behavior of solar cell under the variation of solar irradiance, temperature and some physical parameters such as; series resistance and shunt resistance.

Maps compiled in 2016 suggest that by 2030 the photovoltaic cells could supply around 13\% of global electricity [3, 4]. The territory of Albania is located in the western part of the Balkan Peninsula, at the eastern coast of Adriatic and Ionian seas. It is situated between latitudes $39^{\circ} 38^{\prime}-42^{\circ} 38^{\prime}$ and longitudes $19^{\circ} 16^{\prime}-21^{\circ} 04^{\prime}$ east. Thanks to this

\footnotetext{
* CONTACT: Azemhysa@gmail.com

DOI: http://dx.doi.org/10.28991/esj-2019-01202
}

(C) 2019 by the authors. Licensee ESJ, Italy. This is an open access article under the terms and conditions of the Creative Commons Attribution (CC-BY) license (https://creativecommons.org/licenses/by/4.0/). 
geographical position, Albania belongs to Mediterranean climate belt with hot dry summer, with long days of sunshine and mild winter with abundant rainfall, possessing in this way a considerable solar potential energy: most areas of Albania are exposed to more than $1500 \mathrm{kWh} / \mathrm{m} 2$ per year varying from 1185 to $1690 \mathrm{kWh} / \mathrm{m} 2$ per year [5]. So Albania is a very good place for installation of solar panels.

The characteristic current-voltage and is a non-linear equation with multiple parameters classified as follows: those provided by constructors, those known as constants and the ones which must be computed. Sometimes, searchers develop simplified methods where, some unknown parameters cannot be calculated. They are thus assumed constant [6].

To experiment with photovoltaic cells in the laboratory is a time consuming and costly task. So, to overcome this problem, simulation techniques are used to simulate the behavior of PV cells under different conditions [7].

This paper is presenting a mathematical model of solar array and accomplishes a simulation model in MATLAB®. Output I-V and P-V characteristic curves and performance at different series resistance, shunt resistance, temperature and solar irradiance are analyzed. Thus, this research work is helpful to understand the behavior of the PV cell.

\section{2- Methodology}

The modeling method and numerical experiment for different physical and environment parameters are helpful for power electronics designers, who need a trouble-free and simulation of photovoltaic cells. Mathematical modeling of photovoltaic cells is being continuously updated to enable researchers to have a better understanding of its working. The models differ depending on the types of software researchers used such as MATLAB ${ }^{\circledR}$ [8]. A function in MATLAB ${ }^{8}$ environment has been developed to calculate the current output from data of voltage, solar irradiance and temperature in the study of Gonzaez-Longatt (2005) [9]. Here, the effect of temperature, solar irradiance, and diode quality factor and series resistance is evaluated. A difficulty of this method is to require readers programming skills so it is not easy to follow. Another method which is the combination between MATLAB $\AA \mathrm{m}$-file and C-language programming is even more difficult to clarify [10]. This model is made only in MATLAB, based on mathematical equations that define the photovoltaic cell. From the work of Gonzaez-Longatt (2005) [9], Oi (2005) [11] and Ramos Hernanz et al. (2010) [12] a function in MATLAB $®[10]$ has been developed which calculates the current module from data of voltage, solar irradiance and temperature. Setting the constant temperature or radiation, characteristic curves current-voltage and power-voltage will be obtained. From another script also calculates the maximum power point [13].

Equivalent electrical circuit model is one of the key models under study since the last few decades. It is configured with either single or double diode for investigation of current-voltage relationships [13]. The single diode models usually have five, four, or three unknown parameters with only one exponential term. The five unknown parameters of a single diode model are photo-current $\left(I_{p h}\right)$, diode reverse saturation current $\left(I_{0}\right)$, series resistance $\left(R_{S}\right)$, shunt resistance $\left(R_{s h}\right)$, and diode ideality factor $a[14,15]$. The four parameter model infers the shunt resistance as infinite and it is ignored [16]. The three-parameter model assumes that the series resistance is zero and shunt resistance is infinite and, thus, both of these parameters are ignored, whereas, the double diode models have six unknown parameters with two exponential terms $[17,18]$. In fact, both single and double diode models require the knowledge of all unknown parameters, which is usually not provided by manufacturers.

Nevertheless, the current-voltage equation is a transcendental expression. It has no explicit analytical solution. The analytical methods give exact solutions by means of algebraic equations. However, due to implicit nature and nonlinearity of photovoltaic cell or module characteristics, it is hard to find out the analytical solution of all unknown parameters. Analytical methods have also some limitations and could not give exact solutions when the functions are not given. Thus numerical methods preferred in this case. It is because of the fact that numerical methods give approximate solution of the nonlinear problems without searching for exact solutions [13].

Different methods has used to developed solar cell model. These methods can be categorized in indirect methods and direct. The indirect methods such as heuristic and met heuristic algorithm to predict the five, seven and eight parameters, and direct methods like Newton's method is used in several mathematical and engineering problems to find the numerical solutions of the equations. This method is iterative and iteration sequences converge to an optimal solution of the problem to be solved [19-21]. 


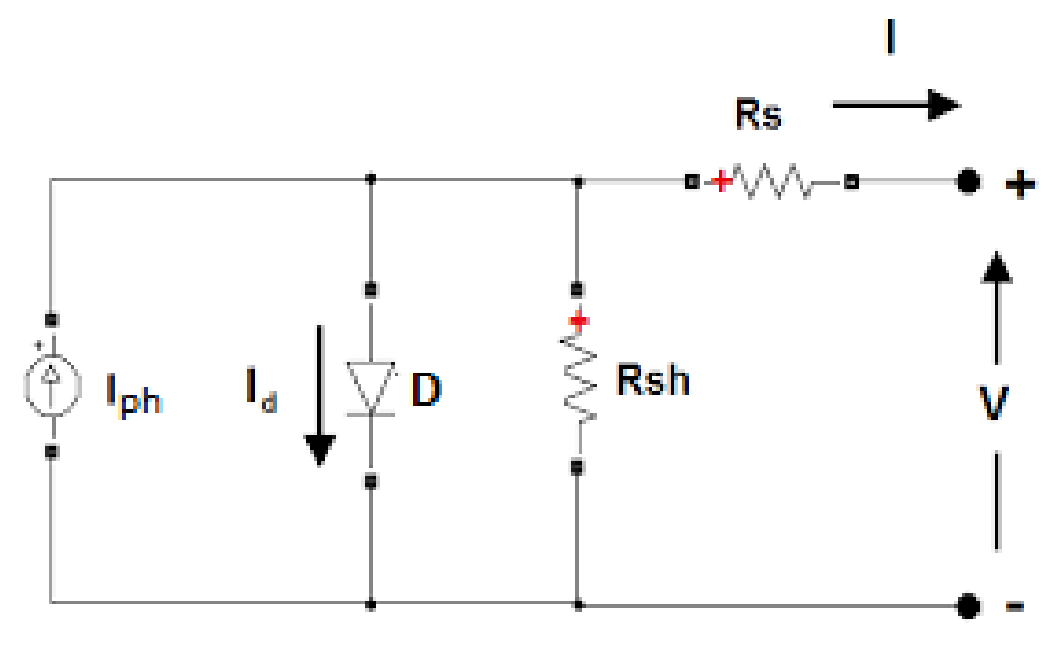

Figure 1. PV cell equivalent circuit.

The practical model of single solar cell is shown in Figure 1. This model can be expressed by the equation which mathematically describes the current-voltage and power -voltage of photovoltaic cell as follows:

$$
I=I_{p h}-I_{0}\left[\exp \left(\frac{V+I R_{s}}{\mathrm{a} V_{T}}\right)-1\right]-\frac{V+I R_{s}}{R_{s h}}
$$

Where $I_{0}$ is the reverse saturation current of diode, a is ideality factor of the diode, $V$ is the voltage across the diode, and $V_{T}=\frac{N_{S} k_{B} T}{e}$ is termed as thermal voltage due to its substantial temperature dependence, $N_{\mathrm{s}}$ is the number of photovoltaic cells modules connected in series, $k_{B}=1.381 \times 10^{-23} \mathrm{~J} / \mathrm{K}$ is the Boltzmann's constant), $e=1.602 \times 10^{-19} \mathrm{C}$ is the electron charge, $T$ is the junction temperature (operating temperature) in Kelvin $(K)$. The photo-current $I_{p h}$ is generated on absorption of solar irradiance by solar cell hence photo-current value is directly related to variation in solar irradiance and temperature and that is $[8,22,23]$ :

$$
I_{p h}=\frac{G}{G_{n}}\left[I_{p v n}+K_{i}\left(T-T_{n}\right)\right]
$$

Where $I_{p v n}$ is rated solar current at nominal weather conditions $\left(25^{\circ} C\right.$ and $\left.1000 \mathrm{~W} / \mathrm{m}^{2}\right)$ or short circuit current, $K_{i}$ is short circuit temperature coefficient, $G$ is solar irradiance in $\mathrm{W} / \mathrm{m}^{2}, G_{n}$ is nominal irradiance in normal weather conditions $\left(25^{\circ} \mathrm{C}\right.$ and $\left.1000 \mathrm{~W} / \mathrm{m}^{2}\right)$ and $T_{n}$ is nominal temperature $=298.15 \mathrm{~K}$. The saturation current of the diode is:

$$
I_{0}=I_{o n}\left(\frac{T}{T_{n}}\right)^{3} \exp \left[\frac{q E_{\mathrm{g}}}{\mathrm{a} k_{B}}\left(\frac{1}{T_{n}}-\frac{1}{T}\right)\right]
$$

Where $I_{o n}$ is reverse saturation current of PV cell for nominal temperature and irradiance values and $E_{\mathrm{g}}$ is band-gap energy of silicon. The reverse saturation current of PV cell is:

$$
I_{\text {on }}=\frac{I_{s c n}}{\left[\exp \left(\frac{V_{o c n}}{\mathrm{a} V_{T n}}\right)-1\right]}
$$

Where $I_{s c n}$ nominal SC is current, $V_{\text {ocn }}$ is nominal OC voltage constant. We know that series resistance is very small then for an ideal solar cell there is no series resistance (no series losses) and no leakage to ground (no shunt resistance) therefore $R_{s}$ and $R_{s h}$ are neglected by putting $R_{s}=0$ and $R_{s h}=\infty$. The expression for ideal cell is simplified for currentvoltage characteristic curves of photovoltaic cell and expression of ideal single cell is as follows [1]:

$$
I=I_{p h}-I_{0}\left[\exp \left(\frac{V+I R_{s}}{\mathrm{a} V_{T}}\right)-1\right]
$$

In the case of short circuit mode, the voltage will be equal to zero and the photo-current is equal to short circuit current $\left(I_{p h}=I_{0}\right)[24]$ :

$$
I=I_{p h}-I_{0}\left[\exp \left(\frac{V}{\mathrm{a} V_{T}}\right)-1\right]
$$

In case of open circuit, the current will be equal to zero, and the voltage is as follows: 
$V_{O C}=V_{T} \ln \left(\frac{I_{p h}}{I_{0}}+1\right)$

The output power is given by:

$P=\left\{I_{p h}-I_{0}\left[\exp \left(\frac{V+I R_{s}}{\mathrm{a} V_{T}}\right)-1\right]\right\} V$

According to PV cell characteristics, current will be maximum when the cell is short circuited. In this case the voltage will be zero $(\mathrm{V}=0)$. The voltage will maximum when the cell's circuit is open. In this case the current is zero ( $\mathrm{I}=0)$. Between the open and short circuit the power output is greater than zero [24].

The Newton iterative method is the most popular iterative method for nonlinear function. Under the first guess and the Jacobian of the nonlinear function can converge very fast. Several papers use the Newton method, to obtain roots of implicit transcendental equations [25]. However, it uses an algorithm which search for the approximations of the roots of function $f(x)=0$ [26]. It starts with a function $f(I)$ defined over the real numbers $I$, the function's derivative $f^{\prime}(I)$, and an initial guess $I_{0}$ for o root of the function $f(I)$. If the function satisfies the assumptions made in the derivation of the formula and the initial guess is close, than a better approximation $I_{1}$ is [27]:

$$
I_{1}=I_{0}-f\left(I_{0}\right) / f^{\prime}\left(I_{0}\right)
$$

Geometrically, $\left(I_{1}, 0\right)$ is the iteration of $I$-axis and the tangent of the graph of $f(I)$ at $\left(I_{0}, f\left(I_{0}\right)\right)$.

$$
I_{1}=I_{k}-f\left(I_{k}\right) / f^{\prime}\left(I_{k}\right)
$$

Where, $I_{k}$ present a $\mathrm{k}^{\text {th }}$ iteration and $I_{\mathrm{k}+1}$ presents the $(\mathrm{k}+1)^{\text {th }}$ iteration, $f^{\prime}\left(I_{k}\right)$ is the derivative of function $f\left(I_{k}\right)$. Using equation (10), the output current of a solar cell can be calculated by modifying the current-voltage in equation (5) as follows [27]:

$$
\begin{aligned}
& f(I)=I-I_{p h}+I_{0} \exp \left(\frac{V+I R_{s}}{\mathrm{a} V_{T}}\right)-I_{0} \\
& f^{\prime(I)}=1+\frac{I R_{s}}{\mathrm{a} V_{T}}+\exp \left(\frac{V+I R_{s}}{\mathrm{a} V_{T}}\right)
\end{aligned}
$$

By exploiting the above equations, following output current is computed iteratively [27]:

$$
I_{\mathrm{k}+1}=I_{k}-\frac{\left[I_{k}-I_{p h}+I_{0} \exp \left(\frac{V+I R_{S}}{\mathrm{a} V_{T}}\right)-I_{0}\right]}{1+\frac{I R_{S}}{\mathrm{a} V_{T}}+\exp \left(\frac{V+I R_{S}}{\mathrm{a} V_{T}}\right)}
$$

\section{3- Results and Discussions}

The obtained result if current-voltage and power-voltage characteristic curves has been produced using m-file MATLAB by varying certain parameters one at a time keeping other parameters constant. The series resistance of photovoltaic cell is low, and in some cases, it can be neglected. However, to render the model suitable for any given photovoltaic cell, it is possible to vary this resistance and predict the influence of its variation on photovoltaic cell outputs.

Figures 2 and 3 shows current-voltage and power-voltage characteristic curves for four different values of $R_{S}$ respectively. As seen in these figures, the variation of $R_{S}$ affects the slope angle of the current-voltage characteristic curves resulting in a deviation of the maximum power point. It was shown that higher values of $R_{S}$ reduce the power output of photovoltaic cell. On another side the simulation was performed for the five different values of the shunt resistance, namely $0.07 \mathrm{ohms}, 0.1 \mathrm{ohms}, 0.15 \mathrm{ohms}, 0.5 \mathrm{ohms}$ and $1700 \mathrm{ohms}$. The shunt resistance of many photovoltaic cells should be large enough for higher output power. In fact, for a low shunt resistance, the photovoltaic cell current collapse more steeply which means higher power loss. These results can be seen in Figures 4 and 5, respectively.

Table 1 shows the distribution of the global average daily solar irradiance in Shkoder, Tirana and Vlore [28]. 
Table 1. The daily average of solar irradiance for some City in Albania $\left(\mathrm{W} / \mathbf{m}^{2}\right)$.

\begin{tabular}{cccc}
\hline City & Shkoder & Tirana & Vlore \\
\hline January & 1734 & 1830 & 1931 \\
February & 2362 & 2468 & 2618 \\
March & 3343 & 3346 & 3535 \\
April & 4431 & 4465 & 4757 \\
May & 5442 & 5602 & 5829 \\
June & 6317 & 6477 & 6753 \\
July & 6571 & 6781 & 6984 \\
August & 5744 & 5990 & 6117 \\
September & 4444 & 4631 & 4808 \\
October & 2997 & 3190 & 3293 \\
November & 1840 & 1981 & 2095 \\
December & 1521 & 1546 & 1680 \\
\hline
\end{tabular}

Figure 6 show the P-V curves for different solar irradiations and constant temperature $T=25^{\circ} \mathrm{C}$ in Tirana. The effect of increasing solar irradiance while temperature was fixed is increasing the output and short circuit current, the output voltage almost not affected very much. Figure 7 show current-voltage characteristic curves for various solar irradiations and constant temperature $T=25^{\circ} \mathrm{C}$ in Tirana. Figure 8 show the power-voltage curves for different solar irradiations and constant temperature $T=25^{\circ} \mathrm{C}$ in Shkoder. Figure 9 show the power-voltage curves for different solar irradiations and constant temperature $T=25^{\circ} \mathrm{C}$ in Vlore. The figures (Figures 6, 7,8 and 9) show that with the increase in irradiance values, the values of the cell current and the maximum power also increase proportionately, but cell voltage increases very less. This is because the open circuit voltage is logarithmically dependent on the solar irradiance, yet the short circuit current is directly proportional to solar irradiance.

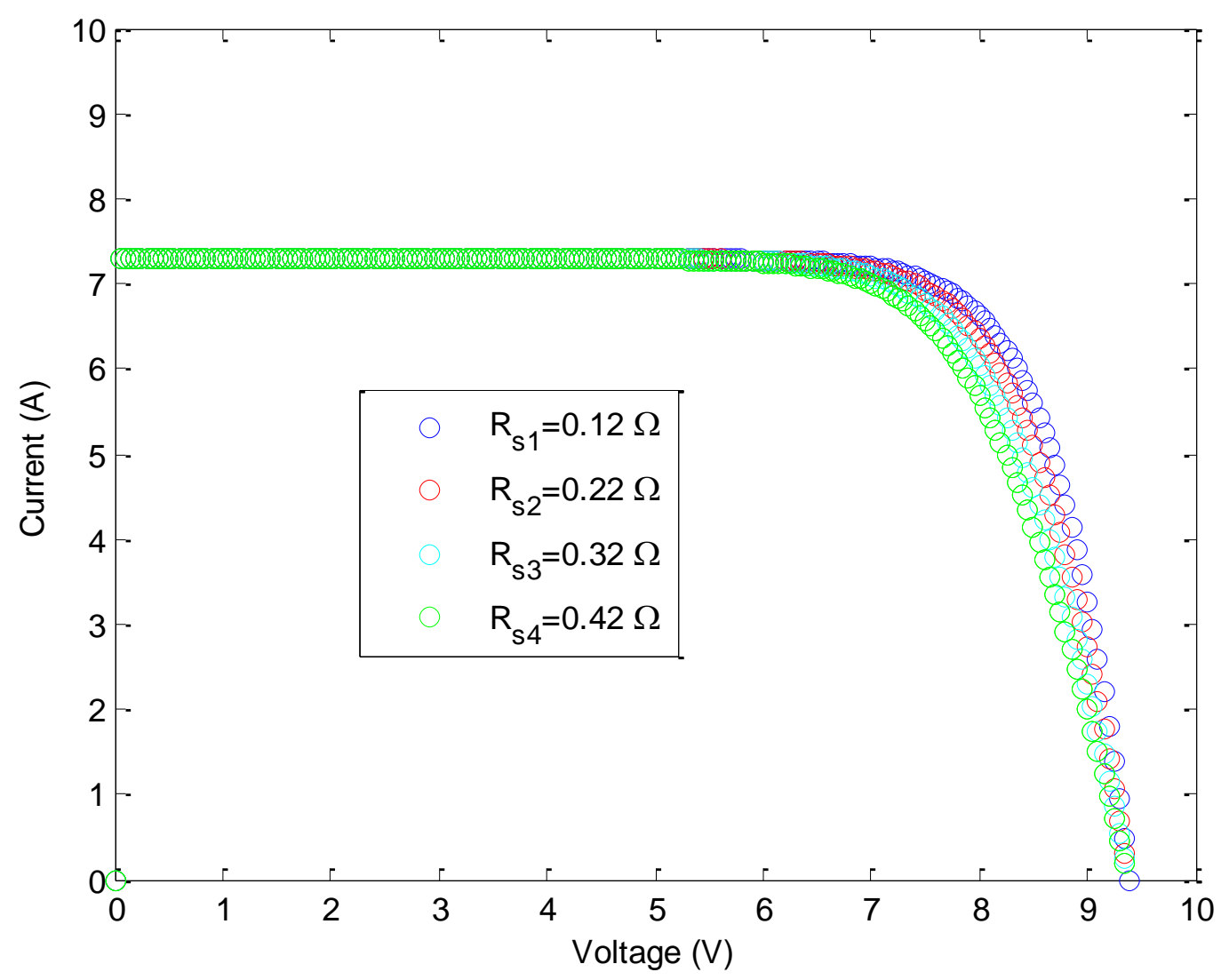

Figure 2. I-V characteristic curves for parametric variation of series resistance. 


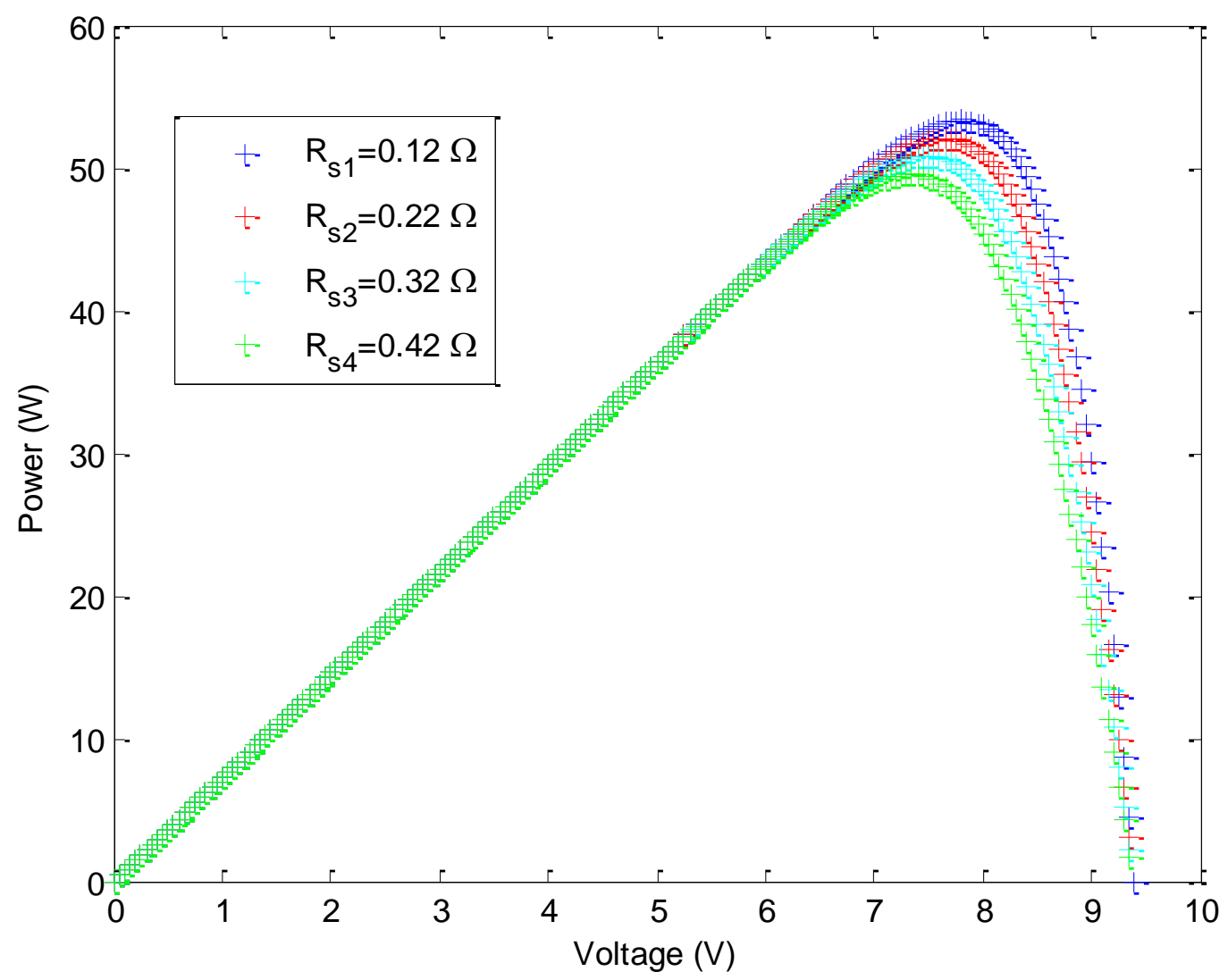

Figure 3. P-V characteristic curves for parametric variation of series resistance.

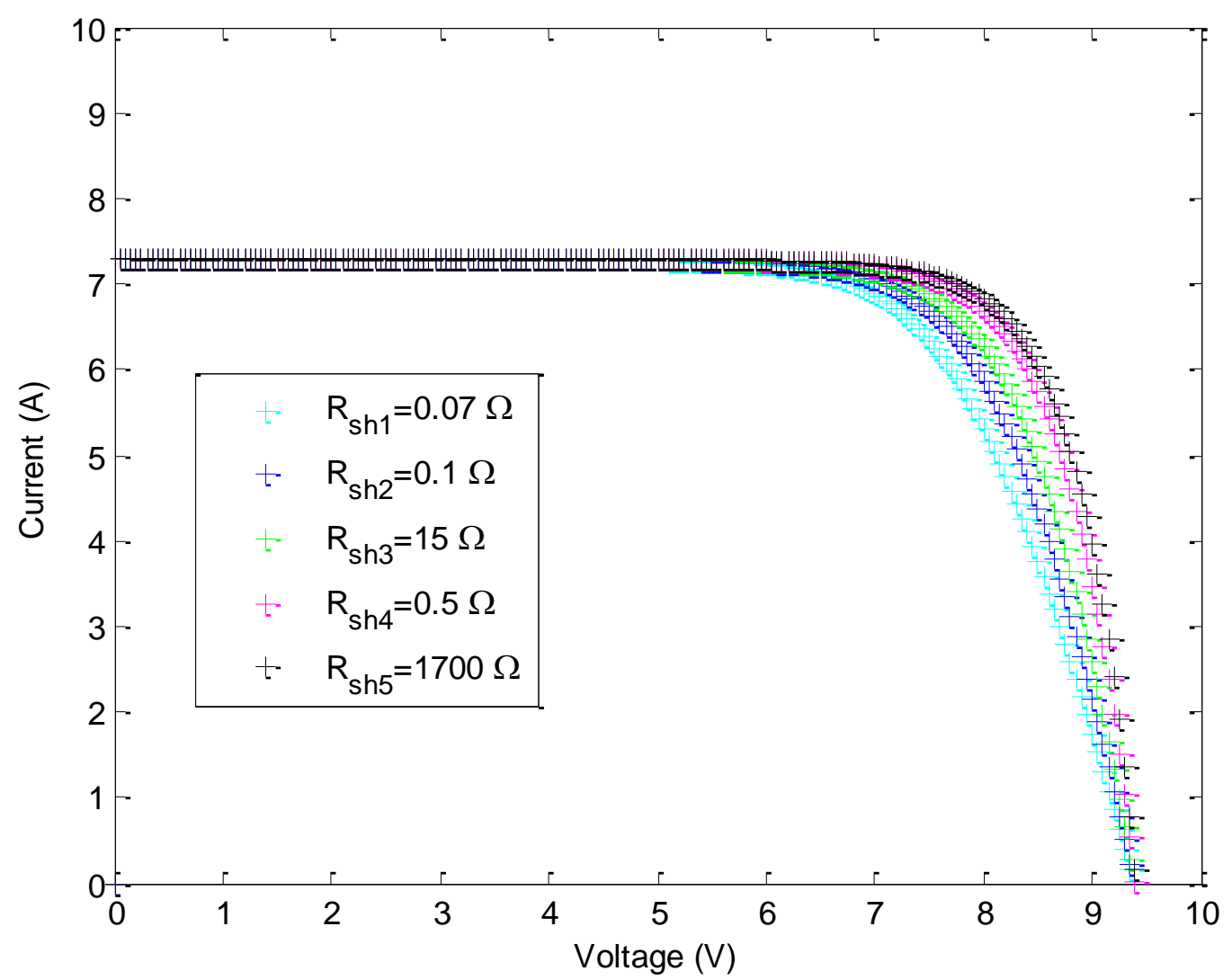

Figure 4. I-V characteristic curves for parametric variation of shunt resistance. 


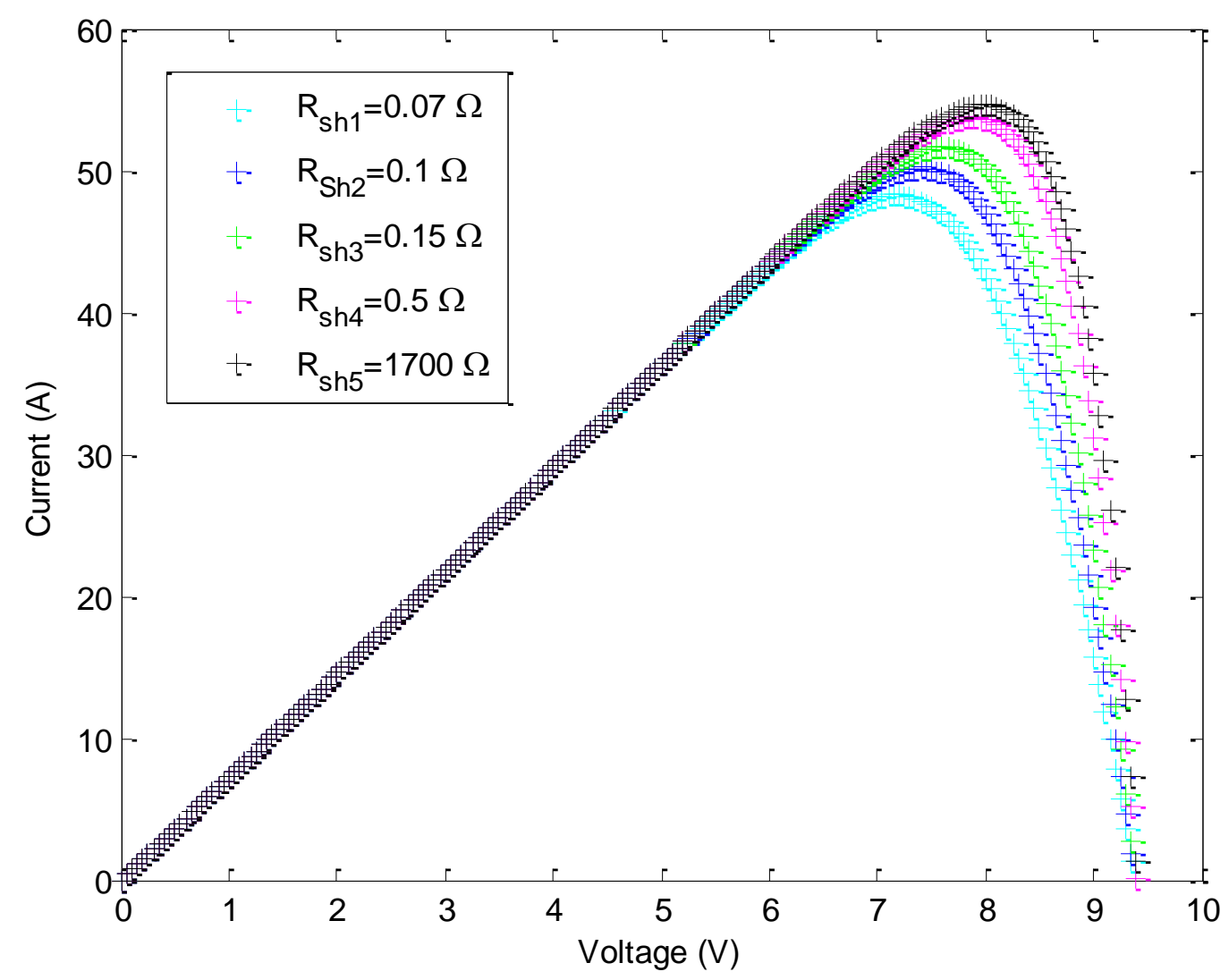

Figure 5. P-V characteristic curves for parametric variation of shunt resistance.

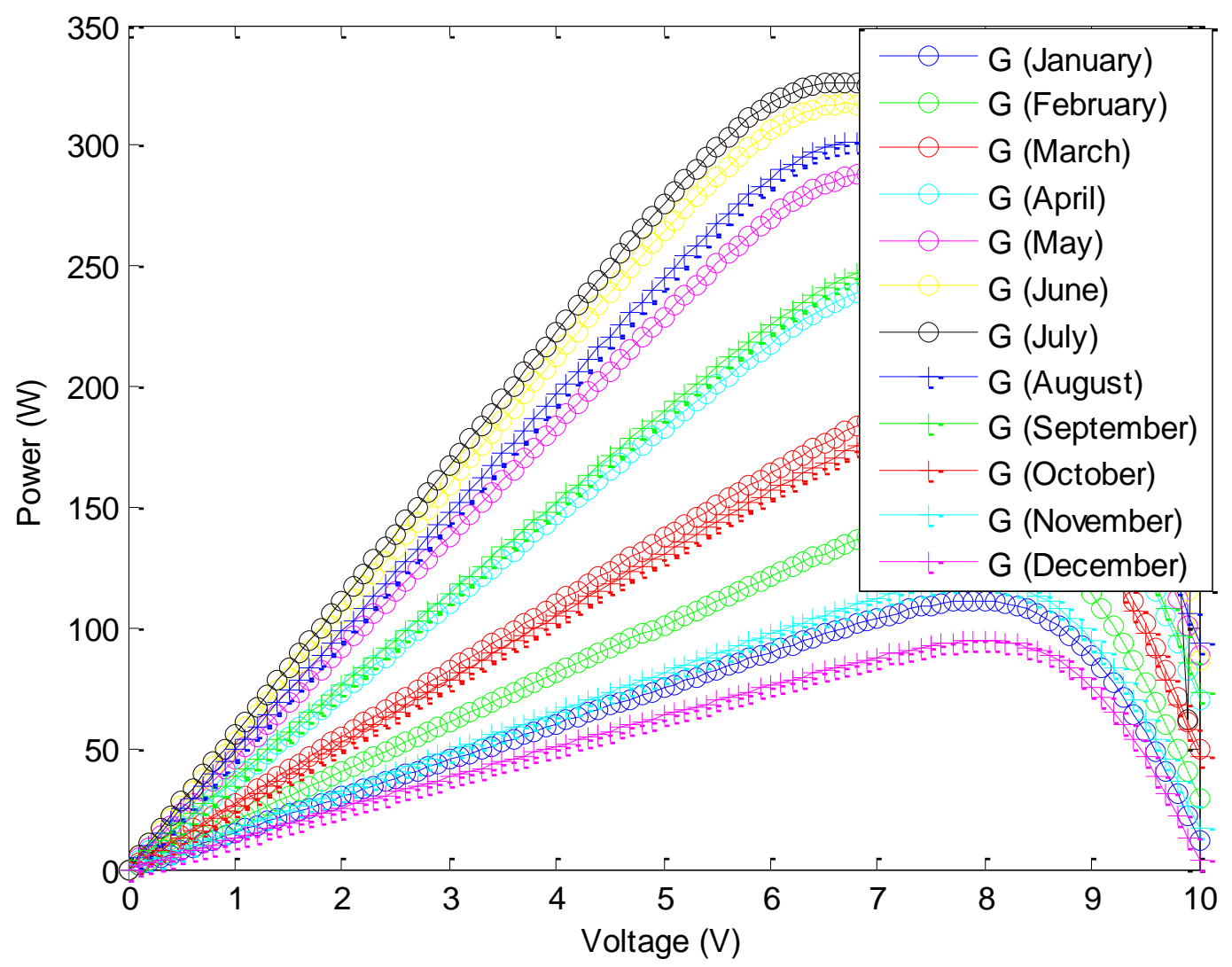

Figure 6. Power-voltage characteristic curves of photovoltaic cells for various irradiation and constant temperature in Tirana, Albania. 


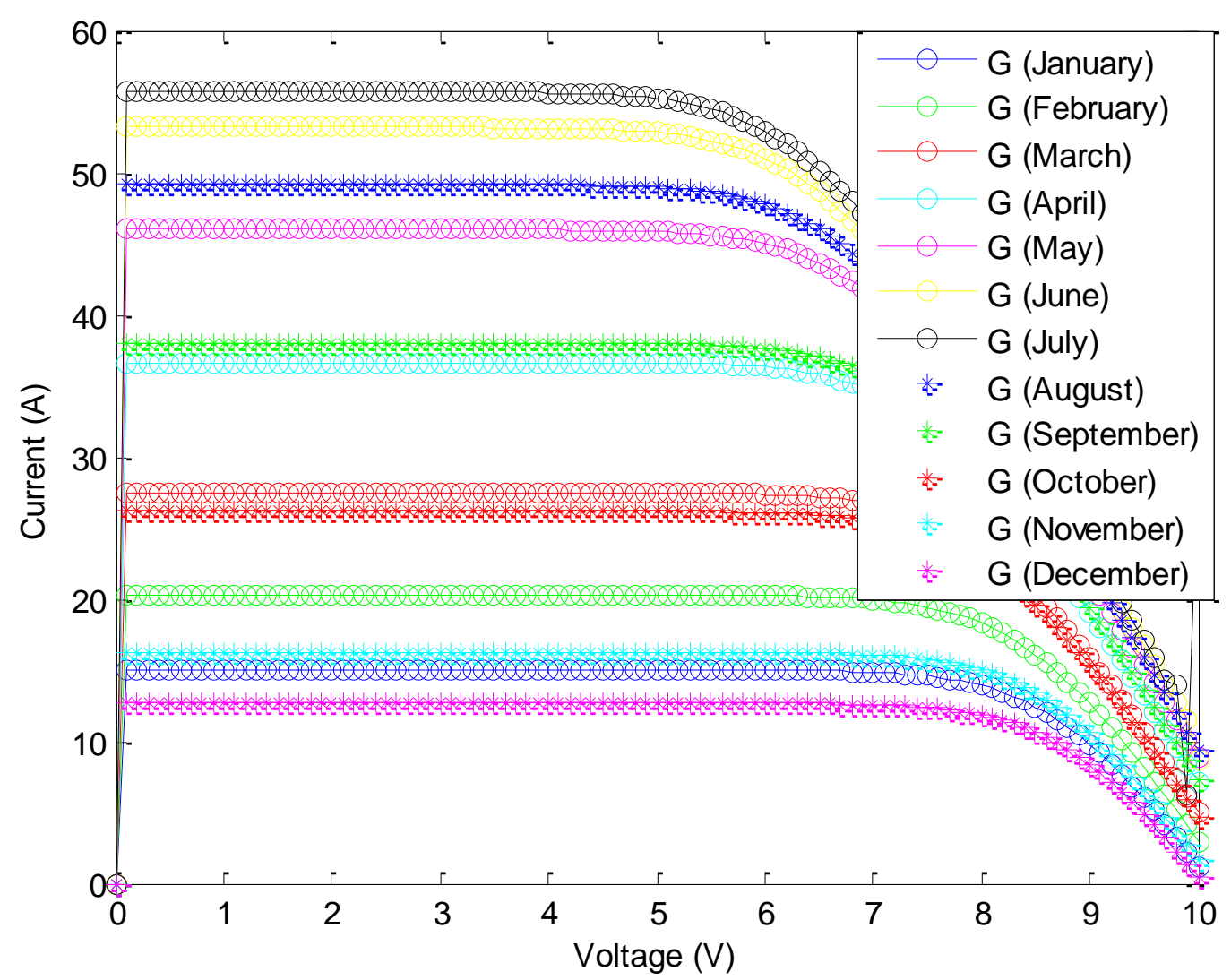

Figure 7. Current-voltage characteristic curves of photovoltaic cell for various irradiation and constant temperature in Tirana, Albania.

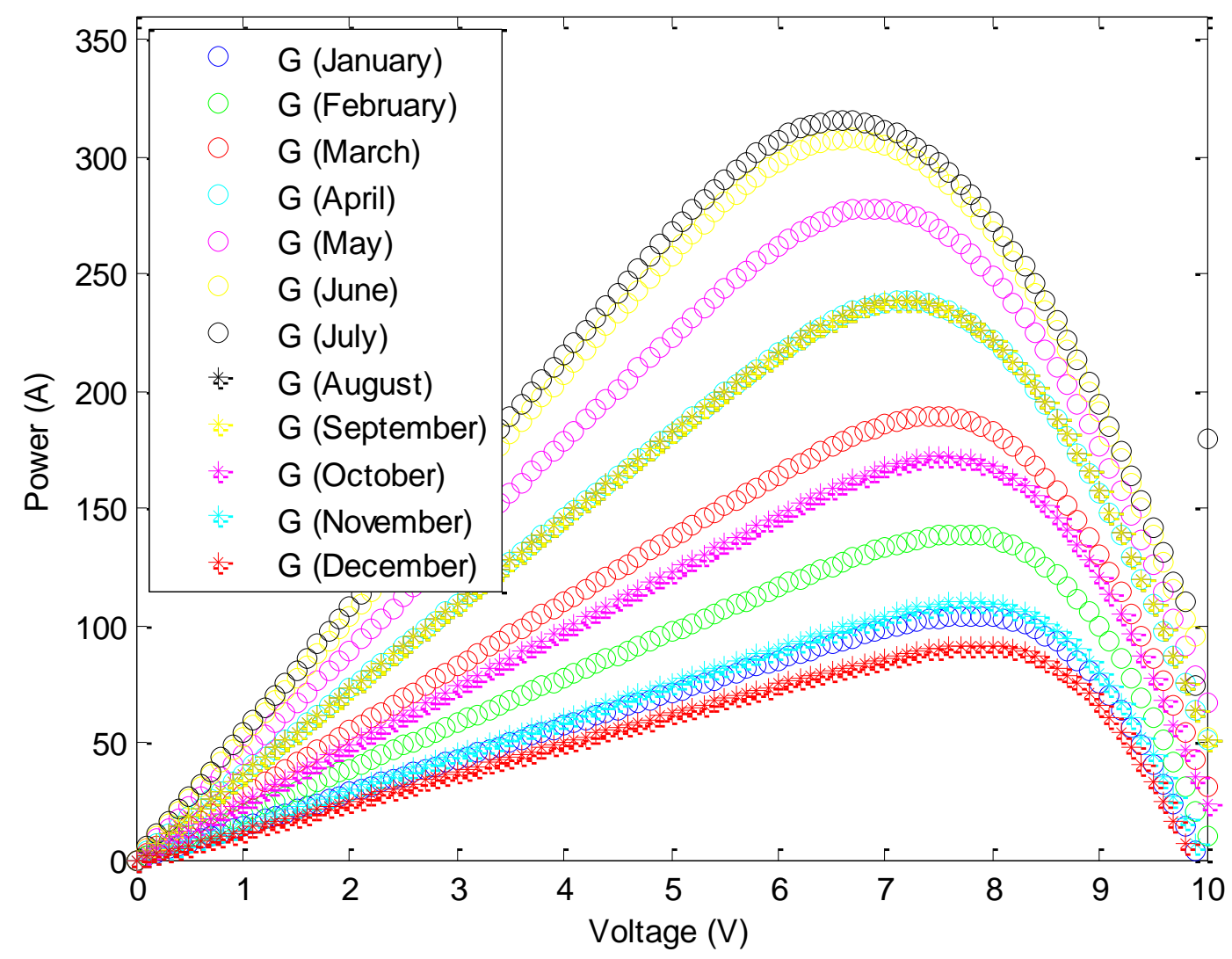

Figure 8. Power-voltage characteristic curves of photovoltaic cells for various irradiation and constant temperature in Shkoder, Albania. 


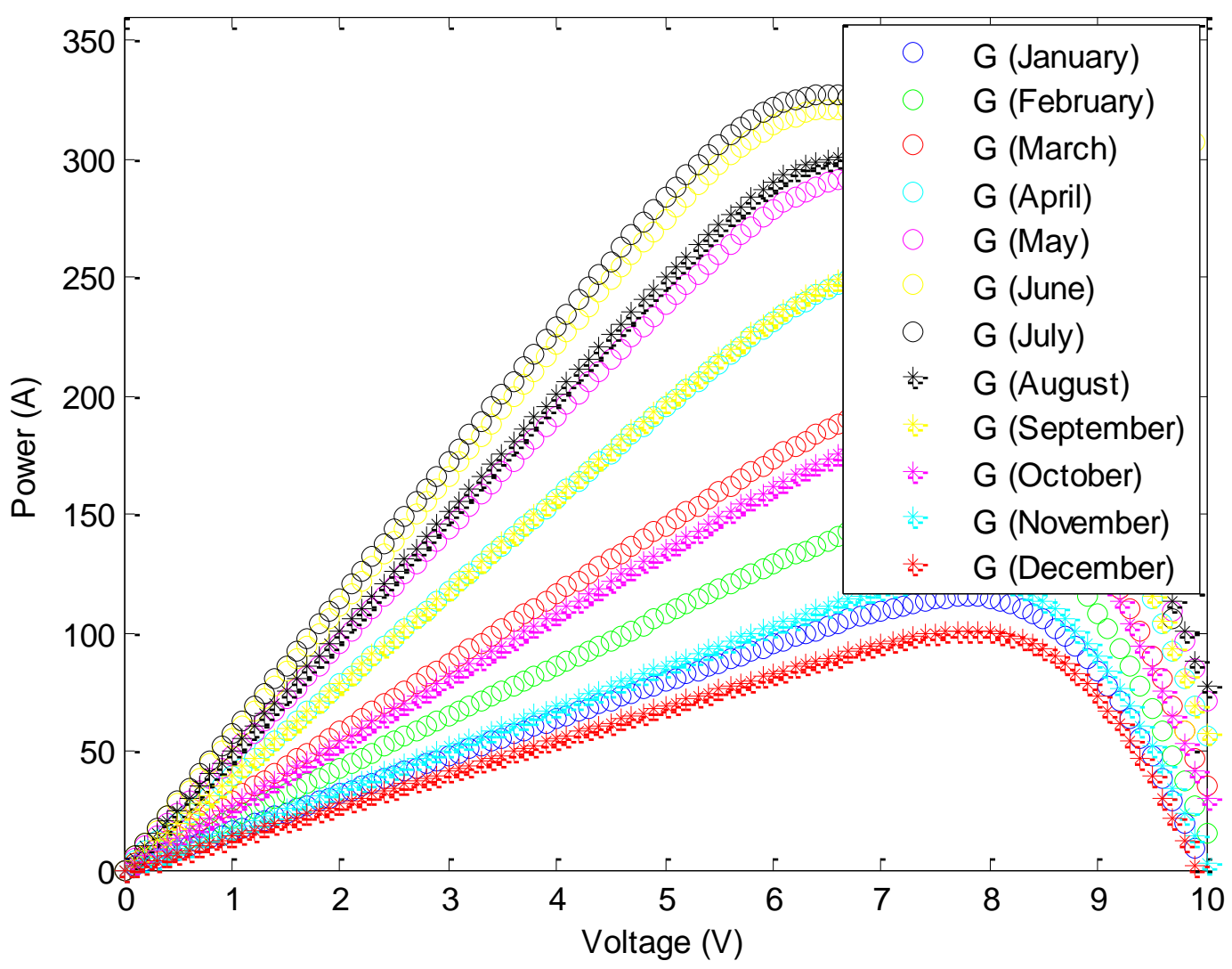

Figure 9. Power-voltage characteristic curves of photovoltaic cells for various irradiation and constant temperature in Vlore, Albania.

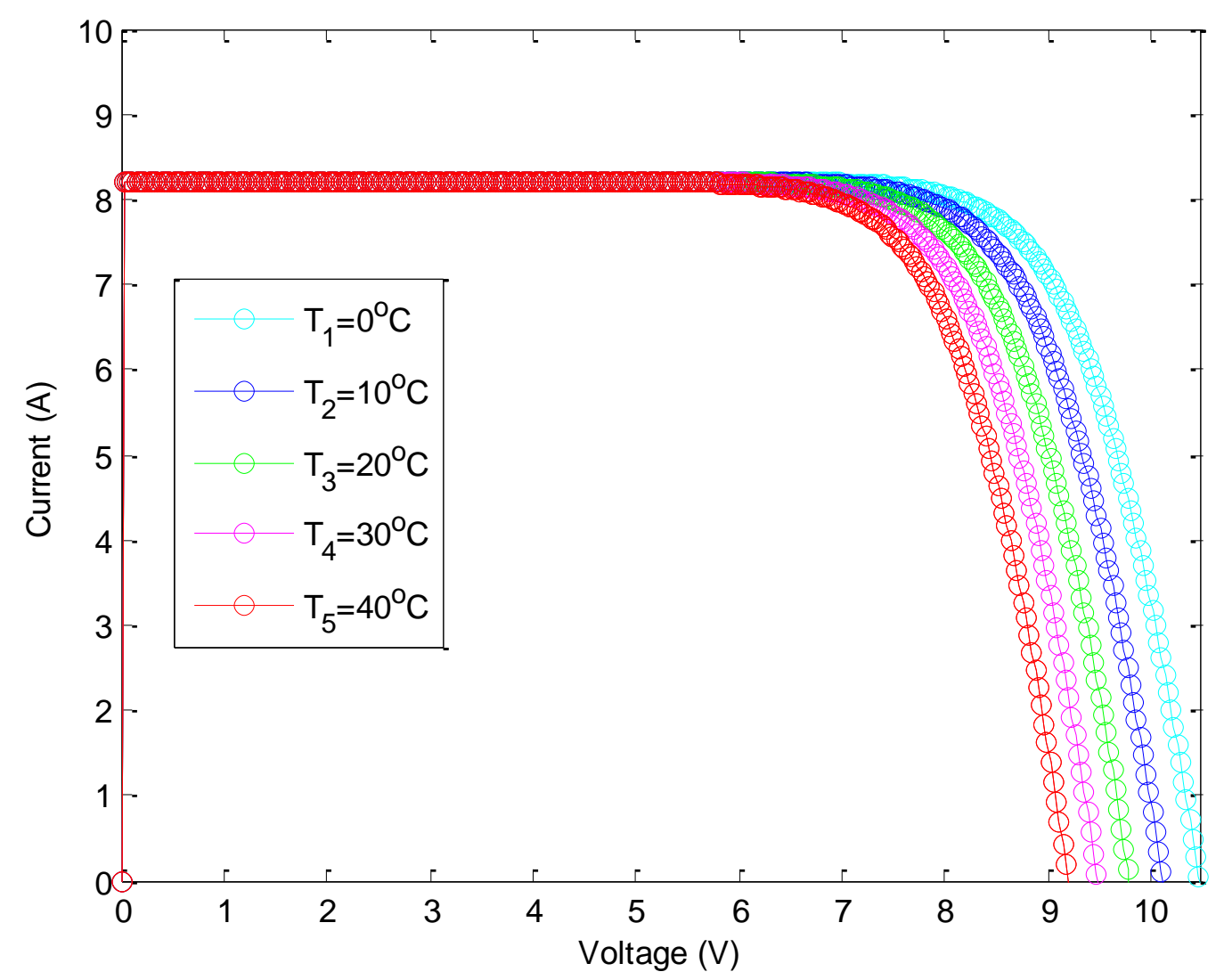

Figure 10. Current-voltage characteristic curves of photovoltaic cell for various temperature and constant irradiation. 


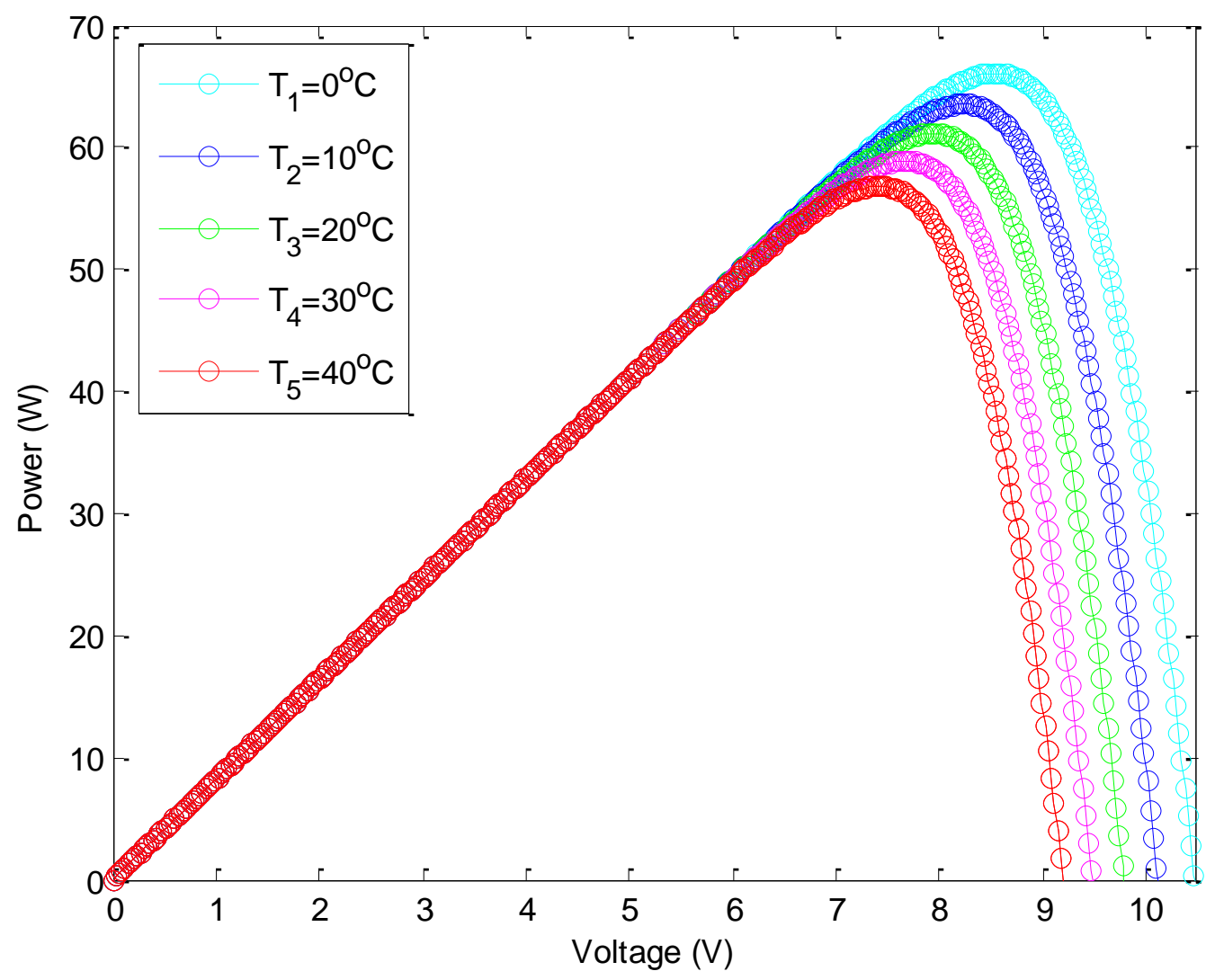

Figure 11. Power-voltage characteristic curves of photovoltaic cells for various temperature and constant irradiation.

Figures 10 and 11 show current-voltage and power-voltage characteristics curves for various temperature $(0,10,20$, $30,40^{\circ} \mathrm{C}$ ) respectively with constant irradiation $\mathrm{G}=1000 \mathrm{~W} / \mathrm{m}^{2}$. The photovoltaic cell's performance was noted to be best at $0^{\circ} \mathrm{C}$. From Figures 10 and 11, it is observed that as temperature increases cell current also increases slightly and cell voltage shows a significant decrease in its value. The increase in the short-circuit current is much less than the decrease in the open-circuit voltage, whereas the maximum power output decreases.

\section{4- Conclusion}

This paper presents the simulation of photovoltaic cells using the software MATLAB $®$. The main objective was to find the nonlinear current-versus-voltage and power-versus voltage characteristics curves for photovoltaic cells. The simulation results showed us that photovoltaic cell output current, voltage and power vary with the changes irradiation, temperature and some physical parameters such as series resistance and shunt resistance. As a result of the study, higher values of series resistance $R_{S}$ reduce the power output of photovoltaic cell.

When shunt/parallel resistance varies between $0.07 \mathrm{ohm}$ and $1700 \mathrm{ohm}$, the current output and voltage output decreases slightly and this results in slight net reduction in power output. However, a significant decrease in current, voltage and power output is recorded when the value of shunt/parallel resistance is $0.07 \mathrm{ohm}$.

As the increase in irradiation the photovoltaic cell output voltage will increase in slightly manner, also, higher magnitude of power will be produced. The change in temperature will affect the behavior of the solar cell, the output current will increase but in negligible value, while the output voltage will decrease, and this will affect the photovoltaic cell efficiency.

\section{5- Conflict of Interest}

The author declares that there is no conflict of interests regarding the publication of this manuscript. In addition, the ethical issues, including plagiarism, informed consent, misconduct, data fabrication and/or falsification, double publication and/or submission, and redundancies have been completely observed by the authors.

\section{6- References}

[1] Abdulgafar, Sayran A., Omar S. Omar, and Kamil M. Yousif. "Improving the efficiency of polycrystalline solar panel via water immersion method." International Journal of Innovative Research in Science, Engineering and Technology 3, no. 1 (2014): 96101. 
[2] Chenni, R., M. Makhlouf, T. Kerbache, and A. Bouzid. “A Detailed Modeling Method for Photovoltaic Cells.” Energy 32, no. 9 (September 2007): 1724-1730. doi:10.1016/j.energy.2006.12.006.

[3] Available online: https://solarpowerrocks.com/solar-basics/how-much-electricity-does-a-solar-panel-produce/, (Accessed on 10 March 2019).

[4] Available online: https://www.ashden.org/sustainable-energy/ashden-guides/solar-for-the-grid, (Accessed on 22 February 2019).

[5] Available online: http://aea-al.org/wp-content/uploads/2012/04/RENEWABLE-ENERGY-ALBANIA.pdf, (Accessed on 08 March 2019).

[6] Bellia, Habbati, Ramdani Youcef, and Moulay Fatima. “A Detailed Modeling of Photovoltaic Module Using MATLAB.” NRIAG Journal of Astronomy and Geophysics 3, no. 1 (June 2014): 53-61. doi:10.1016/j.nrjag.2014.04.001.

[7] Khanna, Vandana, Bijoy Kishore Das, and Dinesh Bisht. "Matlab/simelectronics models based study of solar cells." International Journal of Renewable Energy Research (IJRER) 3, no. 1 (2013): 30-34.

[8] Nguyen, Xuan Hieu, and Minh Phuong Nguyen. "Mathematical Modeling of Photovoltaic Cell/module/arrays with Tags in Matlab/Simulink.” Environmental Systems Research 4, no. 1 (December 2015). doi:10.1186/s40068-015-0047-9.

[9] Gonzaez-Longatt, F. "Model of photovoltaic in MatlabTM." In 2nd Latin American Student Congress of Electrical Engineering and Computer Science (II CIBELEC 2005), Puerto la Cruz, Venezuela. 2006.

[10] Gow, J.A., and C.D. Manning. "Development of a Photovoltaic Array Model for Use in Power-Electronics Simulation Studies." IEE Proceedings - Electric Power Applications 146, no. 2 (1999): 193. doi:10.1049/ip-epa:19990116.

[11] Oi, Akihiro. "Design and simulation of photovoltaic water pumping system." Master Thesis, Faculty of California Polytechnic State University, San Luis Obispo, CA, (2005).

[12] Ramos Hernanz, J. A., J. J. Campayo Martin, I. Zamora Belver, J. Larranaga Lesaka, E. Zulueta Guerrero, and E. Puelles Perez. "Modelling of photovoltaic module." In International conference on renewable energies and power quality (ICREPQ'10). Granada, Spain, (March 2010): 23-25.

[13] Jakhrani, Abdul Qayoom, Saleem Raza Samo, Shakeel Ahmed Kamboh, Jane Labadin, and Andrew Ragai Henry Rigit. "An Improved Mathematical Model for Computing Power Output of Solar Photovoltaic Modules." International Journal of Photoenergy 2014 (2014): 1-9. doi:10.1155/2014/346704.

[14] De Soto, W., S.A. Klein, and W.A. Beckman. "Improvement and Validation of a Model for Photovoltaic Array Performance." Solar Energy 80, no. 1 (January 2006): 78-88. doi:10.1016/j.solener.2005.06.010.

[15] Karatepe, Engin, Mutlu Boztepe, and Metin Colak. "Neural Network Based Solar Cell Model." Energy Conversion and Management 47, no. 9-10 (June 2006): 1159-1178. doi:10.1016/j.enconman.2005.07.007.

[16] Kuo, Yeong-Chau, Tsorng-Juu Liang, and Jiann-Fuh Chen. "Novel maximum-power-point-tracking controller for photovoltaic energy conversion system." IEEE transactions on industrial electronics 48, no. 3 (2001): 594-601.

[17] Chenni, R., M. Makhlouf, T. Kerbache, and A. Bouzid. "A Detailed Modeling Method for Photovoltaic Cells.” Energy 32, no. 9 (September 2007): 1724-1730. doi:10.1016/j.energy.2006.12.006.

[18] Wagner, Andreas. "Peak-power and internal series resistance measurement under natural ambient conditions." In Proceedings EuroSun, Copenhagen, Denmark, vol. 5. 2000.

[19] Louzazni, Mohamed, Ahmed Khouya, Khalid Amechnoue, Alessandro Gandelli, Marco Mussetta, and Aurelian Crăciunescu. "Metaheuristic Algorithm for Photovoltaic Parameters: Comparative Study and Prediction with a Firefly Algorithm." Applied Sciences 8, no. 3 (February 27, 2018): 339. doi:10.3390/app8030339.

[20] Argyros, Ioannis K. "Concerning the Convergence of Newton's Method and Quadratic Majorants.” Journal of Applied Mathematics and Computing 29, no. 1-2 (September 3, 2008): 391-400. doi:10.1007/s12190-008-0140-6.

[21] Argyros, Ioannis K. "On the Radius of Convergence of Newton's Method Under Average Mild Differentiability Conditions." Journal of Applied Mathematics and Computing 29, no. 1-2 (September 10, 2008): 429-435. doi:10.1007/s12190-008-0143-3.

[22] Shah, Md W., and Robert L. Biate. "Design and simulation of Solar PV model using MATLAB/Simulink." International Journal of Scientific \& Engineering Research 7, no. 3 (2016): 551-554.

[23] Nema, Savita, R. K. Nema, and Gayatri Agnihotri. "MATLAB/Simulink based study of photovoltaic cells/modules/array and their experimental verification." International journal of Energy and Environment 1, no. 3 (2010): 487-500.

[24] A.A. Jadallah, D.Y. Mahmood and Z.A. Abdulqader. Modeling and Simulation of a Photovoltaic Module in Different Operating Regimes. Vol. 128 (2015) Acta Physica Polonica A No. 2-B, Special issue of the International Conference on Computational and Experimental Science and Engineering (ICCESEN 2014). 
[25] Bonkoungou, Dominique, Zacharie Koalaga, and Donatien Njomo. "Modelling and Simulation of photovoltaic module considering single-diode equivalent circuit model in MATLAB." International Journal of Emerging Technology and Advanced Engineering 3, no. 3 (2013): 493-502.

[26] Chahid, El Hadi, Mohammed Idali Oumhand, M'barek Feddaoui, Mohammed Erritali, and Abdessamad Malaoui. "Effect of Measurement Factors on Photovoltaic Cell Parameters Extracting." International Journal of Electrical and Computer Engineering (IJECE) 7, no. 1 (February 1, 2017): 50-57. doi:10.11591/ijece.v7i1.pp50-57.

[27] Herbazi, Rachid, Khalid Amechnoue, Ahmed Khouya, and Mohamed Louzazni. "Investigation of Photovoltaic Output Characteristics with Iterative Methods.” Procedia Manufacturing 32 (2019): 794-801. doi:10.1016/j.promfg.2019.02.287.

[28] Available online: http://www.akbn.gov.al/images/pdf/energji-te-rinovueshme/Energjia_Diellore.pdf, (Accessed on 05 April 2019). 